\title{
Collaborative Governance for Sustainable Development in China
}

\section{Berthold Kuhn}

Department of Political and Social Sciences, Freie Universität Berlin, Berlin, Germany

Email: Berthold.kuhn@t-online.de, Berthold.Kuhn@fu-berlin.de

How to cite this paper: Kuhn, B. (2016). Collaborative Governance for Sustainable Development in China. Open Journal of Political Science, 6, 433-453.

http://dx.doi.org/10.4236/ojps.2016.64037

Received: September 14, 2016

Accepted: October 24, 2016

Published: October 27, 2016

Copyright $\odot 2016$ by author and Scientific Research Publishing Inc. This work is licensed under the Creative Commons Attribution International License (CC BY 4.0).

http://creativecommons.org/licenses/by/4.0/ (c) (i) Open Access

\begin{abstract}
The global sustainable development agenda of the United Nations stresses governance and partnerships involving public and private actors as key elements for achieving the sustainable development goals. This paper relates the analysis of China's growing engagement for sustainable development to the concept of collaborative governance. Based on the analysis of literature, policy documents, participation in conferences as well as interviews with experts, it proposes five factors to explain the promising developments of collaborative governance for sustainable development in China: political leadership, discourses, in-country expertise, institutional density and international cooperation. Against the backdrop of a strong government and tightened political supervision in many policy areas under the Xi Jinping administration, Chinese academics as well as practitioners largely agree that the "green development agenda" stands out in providing opportunities for the business community, think tanks and universities as well as nonprofit organisations to implement projects and gradually influence policies and practices related to the promotion of sustainable development.
\end{abstract}

\section{Keywords}

Collaborative Governance, China, Sustainable Development, Agenda 2030, Ecological Civilisation, Green Development

\section{Introduction}

China's engagement with the global sustainability agenda has important implications for the country domestically as well as globally. China has outperformed other countries with its progress on the eight Millennium Development Goals, the predecessors of the 17 Sustainable Development Goals (SDGs) of the United Nations (UNDP, 2015).

The new SDGs are explicitly universal goals. They go much beyond the MDGs by 
requiring developing as well as developed countries to undertake major efforts to integrate environmental and climate protection issues in their development agenda and strike a balance between economic, social and ecological development. The SDGs have been agreed by world leaders on 25 September 2015 at the United Nation's summit in New York. The new ecological dimension of the global development goals of the United Nations is most evident in the Goal 7 on Affordable and Clean Energy, Goal 11 on Sustainable Cities, and Communities, Goal 12 on Sustainable Consumption and Production, Goal 13 on Climate Action, Goal 14 on Life below Water and Goal 15 on Life on Land.

China has played a constructive role in the process of bridging different perspectives between developing and developed countries (Ye \& Fues, 2014). The agreement has received a positive echo worldwide and is considered to be a major global governance achievement given the political and ideological conflicts and diverging economic interests between different countries and nations.

From a political and social science perspective, good governance practices will matter significantly for meeting the ambitious 169 targets of the 17 SDGs, both at domestic and international level. China is a notorious poor performer in several democracy and governance related index projects, including (Bertelsmann Foundation, 2016), Freedom House Index (2016) and Polity 4 Index (Center of Systemic Peace, 2010/2015) and the current Xi Jinping administration is seen to reinforce authoritarian rule in China (Heilmann \& Stepan, 2016). However, China is also known for its remarkable achievements in economic and social reforms and its growing nongovernmental sector, which includes many well- networked and relatively independent organisations dealing with issues related to sustainable development. We have seen recent efforts to discuss the concept of collaborative governance in the Chinese context (Jing, 2015).

This paper will have a closer look at the relevance of the concept of collaborative governance in China in light of multi-stakeholder interaction for sustainable development. Academic interest on governance for sustainable development issues has aroused in the context of the works of Ostrom (1990) and has shaped many academic debates on governing common pool resources. However, with the exception of some chapters in Jing (2015) there are only few attempts (Ngar-in, Mah, \& Hills, 2012; Brown, Gong, \& Jing, 2010) to explicitly relate discourses on collaborative governance to issues of sustainable development in China.

This paper operates with a definition of sustainable development that relates to the work of the United Nations and the frequently quoted Brundtland Report (United Nations' World Commission on Environment and Development, WCED, 1987) and connects to the Agenda 2030's 17 Sustainable Development Goals, with a particular focus on the ecological dimension of the Agenda 2030.

\section{Methodology}

Next to the analysis of literature and policy documents, interaction and interviews with experts are an important source of information to track recent policy orientations and 
assess potentials and limitations of new governance arrangements. Given the many recent developments in the field of sustainable development, including the focus on green development in the 13 Five-Year-Plan (FYP) approved in March 2016, and the emergence of many new institutions and experts in the field, the main sources of information were conferences and workshops in Beijing in spring 2016 and interactions and interviews with thirty experts during this period.

The China Research Group on Socialist Eco-civilization and the School of Marxism of Peking University organised a workshop on Sustainable Development and Environmental Politics on March 8, 2016 to launch and facilitate my research stay at Peking University. The workshop focused on discourses and practices related to sustainable development, with special emphasis on the concepts of ecological civilisation and ecological-marxism. Tsinghua University invited me to the presentation of the Blue Book for Low Carbon Development and the Annual Review of Low-Carbon Development Report on March 17, 2016 (Qi \& Zhang, 2016). Tsinghua Professor Qi Ye discussed the findings with a panel of experts including Nicholas Stern. With the support of the German Embassy, I organised a meeting in Beijing on March 24, 2016 to discuss my preliminary findings and facilitate exchange and future cooperation with academics and practitioners working in the field of sustainable development. The Spring Campus Conference of the University Alliance for Sustainability from April 11 to 15, 2016 in Berlin was another opportunity to discuss my findings with experts from China, mainly Beijing University and Nanjing University.

The group of interviewed experts included academics and practitioners working for think tanks, Universities, NGOs and business groups in China. The decisive factor for selecting the experts with known or demonstrable experience and expertise was mainly their availability for a meeting or an interview in Beijing during the periods of research in spring 2016. Therefore, the methodology was not based on probability samples involving random selection but on non-probability expert sampling which may be considered a subcase of purposive sampling. The interviewed female and male experts were of different age, institutional affiliations and disciplinary background. Most of them were working in Beijing, at Think Tanks or Universities, in business or non-governmental organisations. Some had a background in public administration and management, others in political or environmental sciences. Most of them have long-standing experience in research, policy advisory services and/or project management. It was relatively easy to discuss China's growing commitment to sustainability development with the experts. Their preparedness to discuss governance issues, however, varied. Some perceive governance concepts as strongly rooted in Western theories and normatively loaded. Some of the experts preferred to remain unidentified while others, mainly researchers and experts from independent NGOs, agreed that their names and affiliations could be mentioned, in particular in connection with their publications and public presentations.

This paper links the debates on governance and multi-stakeholder involvement to the promotion of the sustainable development agenda in China. The attempt to identify 
factors that facilitate collaborative governance arrangements fills a gap in political science research and complements research activities based on case studies of environmental governance or governance for sustainable development in China (e.g. Heberer \& Senz, 2011; Yang, 2015).

\section{China's Growing Engagement for Sustainable Development}

China's 13th FYP which has been approved at the National People's Congress annual meeting in March 2016 contains five main chapters, including the chapter on "green development". It is the first FYP developed under President Xi Jinping's leadership and since China's economy entered the "new normal" pace of economic growth. The focus on green development has subsequently been enlarged over the periods of the previous FYP. Tsinghua University's leading expert on sustainable development, Hu Angang, considers the 11 FYP to be the first plan with significant commitment to green development and a turning point with regards to environmental policy making. The period of the 11 FYP marked a decline in energy consumption per unit of GDP after a period of heavy industrialisation during the period of the 10 FYP (2001 to 2005). According to $\mathrm{Hu}$ (2015: p. 151), the 12 FYP is the first plan with a central commitment to green development. China has development its FYP since 1953.

Since the 11th FYP (2006-2010) targets allocated to government responsibility are legally binding and are subject to comprehensive evaluations. In the 12th FYP (20112015), the indicators of green development were grouped into the categories Green Growth, Green Wealth and Green Welfare reflecting a comprehensive vision of green development. According to $\mathrm{Hu}$ (2014: p. 162), the 12 FYP was the first plan to clearly propose a positive response to global climate change.

Energy intensity measured as energy consumption per unit of GDP feel by 18.2 percent in the period 2011 to 2015 . Carbon intensity declined by 20 percent. The main factor was the declining coal consumption, down 2.9 percent in 2014 and 3.7 percent in 2015.

China is on track to meet its commitments under the Paris agreement on Climate Change, which China signed in December 2015 and ratified at the occasion of the G20 summit in Hangzhou in September 2016. With regard to commitments at the international level, China pursues a careful approach and is likely to meet its targets before schedule.

The 13 FYP sets out an annual GDP growth target of 6.5 to 6.7 percent over the next 5 years. The new Plan emphases environmental and climate protection by setting targets for energy efficiency and emissions control. The target for energy consumption per unit of GDP represents a 15 percent decline from 2015 levels by 2020. China aims to achieve acceptable air quality levels in major cities for $80 \%$ of days by the end of 2020 . The electric vehicle market is to be promoted by constructing dedicated parking lots and charging facilities, and removing almost 4 million high-emission vehicles from roads.

China aims to reduce carbon dioxide emissions by 18 percent from 2015 levels by 
2020. This target is in line with China's pledge at the COP21 conference in Paris in December 2015. Total carbon emissions per unit of GDP are to be reduced by $60-65$ percent from 2005 levels by 2030. Targets related to emission reductions vary slightly across different provinces. Less developed provinces are allowed lower reduction targets. China's commitment that carbon emissions will peak by 2030 seems realistic given the indications for a decline of the total coal consumption after 2013. The percentage of non fossil energy sources on primary energy supply shall reach 20 Percent. Forestry area is to be enlarged by 4.5 billion cube meter.

The central government has made urbanisation a central piece of its sustainable development strategy. The urbanisation strategy with a strong focus on smart cities development is a paradigm shift in development policies EU SME Centre \& China-Britain Business Council (2015) and considered to be a major opportunity for effective environment policy making (Qi \& Ye, 2013).

Unlike other emerging and developing economies which are seen to worry about further slum development and political protest movements of city dwellers, China demonstrates a much higher degree of confidence in pro-actively managing the urbanisation process and setting examples for future living standards. In January 2013, the Ministry of Housing and Urban Rural Development (MOHURD) formally announced the first list of national pilot Smart Cities. The project is a joint effort of 11 ministries. By April 2015, there were over 285 pilot Smart Cities in China, as well as 41 special pilot projects.

China is strongly engaged in the United Nations global dialogue initiatives related to sustainable development, in particular in the context of its strong cooperation with the Division for Sustainable Development (DSD) that seeks to provide leadership and catalyse action in promoting and coordinating implementation of internationally agreed development goals, including the seventeen Sustainable Development Goals (SDGs). The Department is headed by the influential Chinese diplomat Juwang Zhu.

In the context of the Implementation of the 2030 Agenda for Sustainable Development, China suggests that nine key areas should be prioritised. These areas are:

- Eradicating poverty and hunger through targeted measures to alleviate and eliminate poverty, and enhancing agricultural production capacities and food security.

- Implementing innovation-driven development strategies and generating momentum for sustainable, healthy and stable economic growth.

- Advancing industrialization to inject impetus to coordinated development between urban and rural areas and among the three dimensions of sustainable development.

- Improving social security and social services to ensure equal access to basic public services.

- Safeguarding equity and social justice to improve people's well-being and promoting all-round human development.

- Protecting the environment and building protective barriers for eco-security.

- Addressing climate change actively and integrating climate change response into national development strategies. 
- Promoting efficient utilization of resources and sustainable energy.

- Improving national governance and ensuring economic and social development in line with the rule of law (Sustainable Development Knowledge Platform, 2015).

China's approach to Health and Age Care is another example that it pursues a comprehensive vision of sustainable development and a strong case for promotion of collaborative governance arrangements. Given the rising living standards and the expansion of the middle class, expectations of Chinese citizens on quality health care and aged care services are rapidly increasing. The 13 FYP promotes the idea of "Healthy China" and encourages the participation of the private sector and social and charity organisations in the establishment of an integrated health and aged care system.

\section{The Concept of Collaborative Governance}

Processes that emphasise contributions of state and non-state stakeholders for consensus-oriented decision-making and policy-implementation constitute the concept of collaborative governance. Collaborative governance brings public and private stakeholders together in collective forums with public agencies to engage in consensus-oriented decision making (Ansell \& Gash, 2007). Collaborative governance arrangements have the potential to tap knowledge from a greater variety of sources and provide wider access to people and institutions. Thus, they provide opportunities to enhance the legitimacy of policy and project implementation. Modern policy-making requires expertise and implementation support from different types of state and non-state institutions in order to ensure compliance with laws and regulations as well as facilitate effective implementation at sub-national levels. The more complex the subject matter is-and the concept of sustainable development is of high complexity-the stronger the case for involvement of a variety of expertise and competencies in collaborative governance arrangements.

Discourses on collaborative governance are connected to the common-pool resource literature (Ostrom, 1990). The academic debates on the challenges for governing common pool resources have proved to be relevant for the emergence of the global sustainability agenda and the integration of the various aspects of environmental and climate protection in the United Nations' Agenda 2030.

Collaborative governance is also entangled with broader concepts of public administration and democracy (Emerson, Nabatchi, \& Balogh, 2011). Deliberative democracy stresses citizen's voice and responsive governance. The entanglement of management oriented governance terms, such as collaborative governance, with normative concepts of democracy explains much of the interest of political scientists on governance discourses. For some, collaborations carry ideological connotations associated with participation and empowerment (Huxham et al., 2000: p. 340).

This paper operates with a more pragmatic concept of collaborative governance, defining it as "multi-stakeholder involvement in the design and implementation of policies and programmes that may exhibit a variety of forms with regards to the level of power sharing and joint decision-making". A more ideologically charged interpretation 
might have alienated scholars in mainland China who are expected to show political sensitivity with regard to the use of theories and concepts that may be considered a challenge to the dominant role of the party state in China.

Compared with the term participatory governance, the term collaborative governance, as understood by the majority of the interviewed experts, puts more emphasis on an "instrumental purpose" (Huxham et. al., 2000: p. 340) and on aspects of management and co-production of outputs or services and, thus, seems more suitable for the political context in China where contracting out of services is high on the agenda and output legitimacy ranks seemingly higher than input legitimacy. Participatory governance, as understood by the author and some of the experts with a political science background, tends to be more associated with input legitimacy, political empowerment and deliberative democracy than the concept of collaborative governance. However, the connection between collaborative governance and power sharing has been explicitly acknowledged by Chinese scholars (Jing, 2015: p. 14) who tend to emphasise the process of subsequently enlarging spaces for non-state actors in the context of collaborative governance arrangement. Jing emphasises the potential of collaborative governance to enhancing competencies and building trust between state and non-state stakeholders. He considers such practices a fertile ground for taking collaboration in design and implementation of projects to higher levels of power sharing in agenda setting and policy formulation (Jing, 2015: p. 14-15).

Governance concepts that emphasise interactions between state and non-state actors in the process of policy making and policy implementation have greatly flourished in western political science theories. The Chinese political science and public administration community has not shown much engagement in academic governance debates. Jing (2015) is one of the few scholars who made an effort to introduce and to adopt western political science concepts of governance to Chinese political and administrative realities. He opted for the concept of collaborative governance to describe the growing influence and participation of non-state stakeholders and quotes a series of examples of collaborative governance practices. His examples include the building of the 2008 Summer Olympic Stadium (Bird's Nest, Liu et al., 2012), nonprofit activism in disaster relief following the Sichuan Great Earthquake (since 2008), the environmental movement against the Nu River Dam (since about the year 2000) and widespread contracting out of public and social services across different levels of government. China is also known for using collaborative governance arrangements in environmental impact assessments and in the process of planning and management of national parks. Pudacuo National Park in Yunnan province was the first national park in China to meet the standards of the International Union for Conservation of Nature.

Governance discourses in the Chinese context mainly adopt a social or environmental management perspective. As long as the academic discourses restraint themselves from questioning the leading role of the sole governing Chinese Communist Party (CCP) or criticize power sharing arrangements within the political system, it seems also possible to tackle governance issues from a public administration or public 
policy perspective. The social governance agenda with its links to public policy and public administration discourses has developed into an accepted field of research.

According to expert opinion gathered in the context of the interviews, such research is meant to shed light on the relationships between the state administration and the growing number of professional, social and charitable organisations. Research and dialogue on collaborative governance arrangements are driven by the purpose to further improve effective service deliveries for public benefit. Based on discourses on "social governance innovations" (she huizhi li chuangxin), Lan (2016) has reflected on "typologies of co-governance in a strong-government context" (Lan, 2016). The term "social governance innovations" has been mentioned in government reports and party documents (Lan, 2016).

\section{Potentials of Collaborative Governance in China}

The visionary concept of sustainable development is meant to generate broad ownership and participation. The United Nations recognise that current development challenges are more complex than they were 15 years ago (UNDP, 2014). New facts, figures and reports, e.g. on the impact of climate change, are constantly influencing the debates. New insights into the expected consequences of climate change require mitigation and adaptation measures. China is engaged in transforming its growth model. The new policy priorities emphasise the rebalancing of growth strategies and a transformation of the economy with more emphasis paid to innovation, coordination between the different levels of government and provinces, ecological and social welfare concerns. China needs broad based support for new policies and programmes to achieve its ambitious objectives.

Some of the interviewed experts forecasted that China will become a global leader in promoting sustainable development. One of the interviewed experts, Hu Angang, has published on the subject matter and has issued a series of pronounced statements of confidence in China's leadership, including "China will lead the world's green energy efforts" (Hu, 2015: p. 39) and "China will become the world leader in developing a low carbon economy" ( $\mathrm{Hu}, 2015:$ p. 40). He is of the opinion that "China will make efforts to shape its industrial structure in line with the need of sustainable development" ( $\mathrm{Hu}$, 2015: p. 39). He argues that China will take advantage of its latecomer position and the strong regulatory and investment capacity of the state to leapfrog in terms of green economic development based on analysis of good practices (Hu, 2015 and interview with Hu Angang on March 12, 2016).

The rising expectations and frustrations of the growing Chinese middle class that are shared via the flourishing social media as well as opinions voiced by globally connected think tanks, business leaders and other experts, have signalled the government to take action in policy areas related to the global sustainable development agenda. The new policy orientations in the context of sustainable development provide opportunities for enhancing collaborative governance efforts at different levels. The complexity of the task plays in favour of extensive consultation with experts and service contracting to 
individuals and organisations with competence in specific areas of proposed government policy action, e.g. eco-friendly city planning, waste management and recycling, carbon emission trading, management of elderly care, pension and insurance reforms.

All interviewed experts agreed that the ecological crisis situation, in particular air and water pollution, is widely acknowledged among decision-makers in China, in particular in mega cities. Air quality and the impact on people's health have become a quasi omnipresent topic of concern. Many of the interviewed experts from University and think tanks provide advisory services to local and central government departments in the field of eco-city planning or legal and policy advisory services related to social and environmental issues. They referred to a growing recognition among the bureaucracy that the transformation process requires knowledge, expertise and implementation support from experts and non-state institutions to raise awareness, increase knowledge and compliance with policies, laws and regulations and improve effective implementation of projects, in particular at sub-national levels.

In contemporary Chinese history, new policy orientations following crisis situations facilitated the reconfiguration of governance arrangement. Following many years of economic crisis, the post 1978 open-door policy has opened spaces for market actors and fuelled the development of the private sector. The private sector has quickly developed in China. The unleashing of market forces have led to unprecedented period of economic growth which has in turn boosted the legitimacy of the government. Next to continued growth, social and environmental issues have become urgent challenges for the government at different levels. The Chinese Government as well as nonprofit organisations has now "joined the bandwagon of service contracting with enthusiasm" (Zhao et al., 2016: p. 2231).

The Chinese research community has carefully analysed the welfare state arrangements in western countries. Zhou et al. pointed out that "theories and practices of government-nonprofit relations in the West have significantly shaped the research and policy discourses on this issue in China" (Zhao, et al., 2016: p. 2233). Western welfare systems rely on outsourcing of services. Many NGOs, in particular in European countries, heavily depend on government funding. The government is able to exercise control through the provision of service contracts. Zhao et al. (2016) discuss the potential advantages and disadvantages for NGOs involved in subcontracting arrangement with the government. They stress the crowding in effect, in particular if the recipient is politically sensitive. Unlike in some Western countries, they did not find evidence for a crowding out effect - government service contracting did not cause a dec 4 crease in private donation (Zhao et al., 2016: p. 2245).

Service contracting enables collaborative governance in many ways. Jing (2015: p. 14-15) emphasises the aspects of power sharing through effective delegation of regulatory power, accumulation of trust through successful cooperation between government and contractors and the entry of external organisations into local communities.

Collaborative governance arrangements between state and non-state actors have the potential to tap knowledge and competencies from a variety of sources to solve collec- 
tive action problems. Inspired by Ostrom (1990), an extensive common pool resource literature has developed in the past decades. In literature, the award winning, highly successful Blackfoot Challenge case of collaborative watershed management in Montana shows that collaborative efforts engaging local communities in public problem solving contributes to forging strong, productive links between government agencies and local expertise (Weber, 2012: p. 35).

Yang (2015) discussed governance arrangements for grassland degradation in Inner Mongolia, the largest grassland region in China and part of the largest grassland in the world. She points out that "multicollaborative governance has already been practiced for several decades as a response to the failure of using a single governance model or type. With regard to China and the strongly expanding supply of wind energy, Ngarin, Mah, \& Hills (2012: p. 85) suggest that "while the central government has an important role to play, there are many opportunities for locally based collaborative initiatives to function as an alternative, complementary approach to facilitate Wind Resources Assessments that have been identified as a key impediment to the further development this energy source. Scholars typically emphasize the strong role of the government in China. In the emerging field of sustainable production and consumption - corresponding with the SDG 12-Schroeder (2014) pointed out that experts tend to place more emphasis on top-down government rather than on bottom-up NGOs initiatives for addressing unsustainable practices of production and consumption. However, they still stress the complementary contribution of the bottom-up initiatives. Kuhn \& Zhang (2014) arrived at similar conclusions with regards to climate change awareness in China: Government discourses and policies matter most, but there are many other factors that influence growing awareness on climate change in China.

\section{Limitations of Collaborative Governance in China}

The case of China raises the question to which extent collaboration is nested within democratic values and how it impacts on political power sharing arrangements. While the Chinese state sets many incentives for collaboration with non-state institutions, the authoritarian character of the political system and the hierarchical structure of the state bureaucracy hinders the flow of information and the spread of knowledge good practices. China's policy style of experimental policies and its support to pilot projects, however, compensates for it in many ways. China aims to pursue evidence-based policy-making and shows an ability to learn from successful local experiments which often provide significant space for business or social organisations. The most challenging aspect for authoritarian political systems in promotion innovations is to strike a balance between rapid mainstreaming of innovations, new norms and practices and political and social control of new developments. There is no doubt, that serious policy implementation gaps, including some perverse incentives (Ran, 2013), still exist in China and need to be addressed in order to successfully manage green transition. Florini, Lai, \& Tang (2012: p. 178) emphasise that the need for deep economic reforms might trigger further change in the direction of more networked approach to governance and associ- 
ate several benefits with multi-actor approaches in terms of resilience to challenges that arise in today's globalising China.

China's political system has been labelled as fragmented authoritarianism (Lieberthal \& Lampton, 1992; Heberer, 2006; Mertha, 2009). This term suggests that the political system is rooted in authoritarian foundations but displays a considerable degree of variety between different styles of policy making and governance arrangements across sectors and topics. The interviews with the experts confirmed that policy areas and issues relevant for the promotion of sustainable development, including environmental and social policies, are not usually among those areas and issues which demonstrate the more authoritarian character of the Chinese political system.

The term of fragmented authoritarianism reflects the struggle of political science research to capture the complex reality of government and governance in China which escape more or less simple categories developed by democracy index projects such as Freedom House or Bertelsmann Transformation Index. The interplay of communist rule with a growing market-oriented economy and an extension of the number and activities of non-governmental organisations seems to make political analysis and forecasts extraordinary difficult. It currently results in the development of different political scenarios which show considerable variations with regard to the stability, resilience, political reform and policy implementation performance of the political system of China (Bertelsmann Foundation, 2016).

Compared to the periods of severe national economic crisis and strong domestic political struggles in the 1960s and 1970s in which authoritarian political rule and economic planning, restriction of civil freedom and social control were at their peak, the situation in contemporary China has much changed in the context of the market reforms after the open door policy, China's integration into the world economy and it growing engagement in global policies, including the sustainable development agenda. The fight of the Xi Jinping administration against corruption, tightened media control and confrontation with other nations in the South China Sea, have provoked political analyses that suggest more confrontations between the West and China (Gippner \& LSE, 2016).

However, signs bode well that the sustainable development agenda, including the global fight against climate protection, continues to be seen by China as an opportunity for cooperation rather than confrontation. Such analysis explains China's continues interest in learning about sustainable development solutions in different countries and applying good practices of collaborative governance in China.

\section{Factors Facilitating Collaborative Governance for Sustainable Development}

Based on the interactions and interviews with the selected experts, the author filtered five factors that best present the opinions and statements of the experts on "what matters for the development of collaborative governance arrangements for sustainable development in China". The five factors which were eventually prioritised were leader- 
ship, discourses, institutional density, in-country expertise and international cooperation (Figure 1).

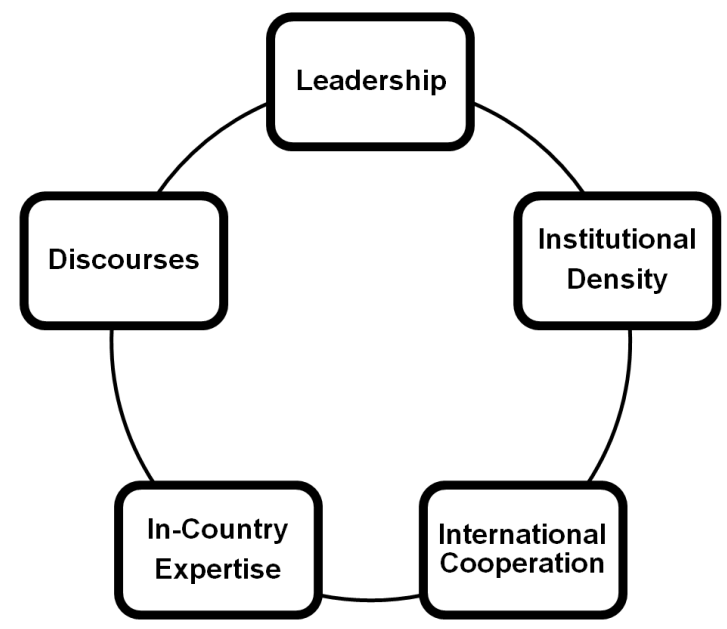

Figure 1. Factors facilitating collaborative governance for sustainable development.

The following sections explain the context of the five factors in the light of the political situation and the status quo in China in the period 2015 to summer 2016.

\subsection{Political Leadership}

The influence of the political leadership factor on promoting the sustainable development agenda at different levels has been quoted by many of the interviewed Chinese experts, including those with a research and NGO background. China views its engagement in combating climate change as a chance to become an integral part of global leadership (Zhang, 2015: p. 330). However, it has been observed from interactions at conference and workshops, including several workshops at the Mercator Institute of China Studies in Berlin in the years 2015 and 2016 (www.merics.org) that non-Chinese researchers, especially those with a political science background, show reservations regarding the positive contributions of the current Chinese political leadership to advancing sustainable development policies.

Political power in China is largely monopolised by the single ruling Chinese Communist Party (CCP). The President is not elected by universal suffrage and checks and balances between executive, legislative and judicial power do not meet the democratic standards of multi-party democracies. Political and media freedom is significantly lower than in western democracies (Freedom House, 2016; Bertelsmann Foundation, 2016). However, party and political-administrative leadership has been highly institutionalised in the past decades, in contrast to the years under Mao Zedong's rule.

Among leading international environmental experts, it has been widely acknowledged that the current political leadership of China is strongly committed to transforming the Chinese growth model (Green \& Stern, 2015; Stern, 2015; Tiezzi, 2015). The central leadership has made substantial contributions to environmental policy reforms and the promotion of the concept of sustainable development. President Xi's at- 
tendance of the United Nations summit on the Agenda 2030 in New York in September 2015 and his participation in the COP 21 meeting in Paris have made media headlines in China and abroad contributing to the word-wide attention to the Agenda 2030 and the Sustainable Development Goals of the United Nations.

The interviewed experts also referred to the leadership factor in connection with the positive role played by Chen Jining, the Minister of Environment and former president and vice-president of Tsinghua University, who has been quoted to be "a rising star in Chinese politics" (Bo, 2015). Minister Chen has been involved in policy making on environmental issues in China for a long time and in different functions, including as a member of the National Environmental Advisory Commission, Deputy Chairman of the Science and Technology Committee of the Ministry of Environmental Protection, Vice President of the Chinese Society for Environmental Sciences, and board member of the Chinese Environmental Foundation.

\subsection{Discourses}

The political leadership embraces sustainable development discourses and also promotes the development of home-grown discourses with Chinese characteristics. The many discourses in China that relate to the various environmental, social and economic objectives of the sustainable development agenda explain China's shifting development priorities and the increasingly constructive role it plays at the global level.

The growing breadth and diversity of discourses have prepared the ground for spreading awareness and creating ownership on the concept of sustainable development and related discourses in China have been described by Kuhn (2016). We observe discourses that have been shaped by the top level leadership (e.g. harmonious society), spread by collaborative efforts of state and party intellectuals and practitioners (e.g. ecological civilisation) while others connect more to China's involvement in international cooperation (e.g. low carbon development) or academic theories e.g. (ecological marxism).

Ecological Civilisation: The term of ecological civilisation is part of a series of visionary discourses about civilisations, societal transformations and economic reforms that have a long tradition in communist China. The policy of ecological civilisation has been incorporated into the CPC Charter at the 18th CPC National Congress in 2012 and is since considered to be a key element of China's national development strategy.

Harmonious Society: The concept of harmonious society has been developed as an all-encompassing vision for social and economic development towards a prosperous and peaceful China under the leadership of the $\mathrm{Hu}$ Jintao/Wen Jiabao administration as a response to growing social injustices and inequalities in mainland China.

Scientific Outlook to Development: The term has been promoted by the Hu/Wen administration and stands for China's vision to focus on research and innovations as drivers of development.

China Dream: Discourses on China Dream have developed after 2013 in response to debate on China's new economic and social visions in connection with developing "a 
moderately well-off society" and promoting sustainable development.

Beautiful China and Beautiful Life: The term "beautiful China" was coined by the political leadership at the 18th CPC National Congress in November 2013.

China's New Normal: "China's New Normal" is a top-level economic policy discourse shaped by speeches of President Xi and top government officials to describe a rebalancing of the Chinese economy in the direction of sustainable growth.

Green Development and Green Growth: "Green" is a popular term for ecologically minded concepts and activities in China. The term "green development" has been elevated to the rank of a top policy priority in the context of the elaboration of the $13 \mathrm{FYP}$ (2016 to 2020).

Circular Economy: The 11 Five Year Plan contained a chapter on circular economy and a circular-economy 'promotion law' was promulgated in 2008. The 12th Five-Year Plan (2011-2015) upgraded the concept to a national development strategy.

Low Carbon Development: The term "low carbon development" has been promoted in the context of local policy experimentation and international cooperation. Tsinghua University has published a series of Low Carbon Development reports.

Ecological Marxism: The concept has been embraced by a number of researchers at renowned Chinese Universities and reflects efforts to link Marxist theory to green movements and constructive post-modernism (Wang \& Fan, 2014).

\subsection{Institutions}

China accounts for a high density of political, economic and social institutions. Abbot et al. (2012) have taught us that world politics is characterised by an increased density of institutions, in particular private institutions, and that cooperation prevails over conflict. Though not targeted at China, some of their arguments-the number of private organizations will increase relative to the number of intergovernmental organizations (Abbot et al., 2012) — can be borrowed to better understanding the process of growing institutional density in China, too. In China, the number of private organizations has grown more rapidly than that of public organizations. Mainland China accounted for about 662,000 registered NGOs by the end of 2015 (China Daily, 2016).

Sustainable development discourses and related policy-making are based on extensive dialogue and consensus seeking of stakeholders inside and outside government that are led by a dominant agency of central government. Hart et al. (2015) mapped China's climate policy formation process and described the mandates and role of different Government departments, think tanks, and business groups. They acknowledge the high institutional density and strong cooperation at central level and consider oversight of implementation at the level of provincial and local governments which often resist higher regulatory standards as the biggest challenge (Hart et al., 2015: p. 40).

The National Development and Reform Commission (NDRC) is the most powerful player in shaping China's approach to sustainable development. The concept of sustainable development cuts across different sectoral competencies of Ministries. This plays in favour of a strong role of a coordinating agency and supports NDRC's claim 
for leadership. The need for strong ownership, however, makes contributions from other players indispensable.

While the Ministry of Foreign Affairs is chiefly in charge to negotiate China's commitments and contributions at the international level, NDRC has a specific mandate to play a coordinating role in national policy development. Within, NDRC, the National Energy Administration, established in August 2008 to replace the National Energy Bureau, and the Department of Climate Change, also established in 2008, are key units within NDRC's engagement with sustainable and green development. The Department of Climate Change is responsible for implementing China's emissions trading pilots and national trading scheme.

With regard to sustainable development, the task force China's Agenda 21, created under the State Council, is mandated with supporting China's sustainable development goals and is worth noting. Its members include ministries, key government agencies, trade associations groups and other state agencies concerned with progressing these goals. The Ministry of Science and Technology plays the leading role in China's Agenda 21 in their focus on energy policies and carbon emission reduction through efficient, renewable energy, and clean-air technologies. It is also developing South-South cooperation with a focus on technology partnerships and transfers.

Other Ministries, in particular the Ministry of Environment, are also considered key players in the field of sustainable and green development. Experts pointed out that the Ministry of Environment has a stronger engagement with non-state stakeholders than NDRC and other Ministries, perhaps with the exception of the Ministry of Civil Affairs which is an active dialogue partner for NGOs and organises an annual China Charity Fair. The interviews with experts confirmed that access and cooperation to the Ministry of Environment is easier for non-state stakeholders than access to NDRC. NDRC has strong departments and associated think tanks, but only a few of the interviewed academics enjoyed close direct cooperation with NDRC. Within the MEP, the Department of Science, Technology and Standards is responsible for climate change policy matters.

China's environmental administration, which was elevated to the rank of a Ministry in the year 2008, has a long-standing reputation for collaborative governance with involvement of experts and NGOs, such as Ma Jun and the Institute of Public \& Environmental Affairs (IPE). Environmental governance under long-time vice minister Pan Yue (2008 to 2015) included naming and shaming of most seriously polluting industries.

Outside the realm of the state, we also witness the formation of policy communities in renewable energy sector as well as a growing network of environmental NGOs. The rising influence exercised by non-state or quasi-state actors in government decisionmaking processes has been widely recognised (Kennedy, 2005; Lieberthal \& Oksenberg, 1988). In China, it today also includes the solar and wind energy industries. In an attempt to strengthen the independence of local Environmental Protection Bureaus (EPB), a recent development under the new Minister of Environmental Affairs includes a requirement for data transfers and reporting directly from EPB to provincial level 
authorities. Xue Lan, Dean of the Tsinghua University's School of Public Policy and Management, considers this to be an important change for improving the quality of data and reports (Panel Discussion at Hertie School of Governance in Berlin, October 7, 2016).

With regard to nongovernmental organisations, several action-oriented networks emerged in China in the past decade. The Green Choice Alliance which was started in 2007 provided some of its most active members with good protection and support to stand-up against the pressure of some polluting industries. The activities of the network also enjoy some protection and cooperation from the Government. An example of collaborative action on polluting industries is the publishing of pollution data of leading companies obtained from the Ministry of Environment and published by the IPE, one of the leading members of the Green Choice Alliance.

IPE also reports a high level of collaborative engagement with the private sector, exemplified with Apple Inc. IPE executed an investigation on Apple's suppliers, previously kept secret by the company, which revealed twenty Apple suppliers with heavy pollution records. Subsequently, Apple changed its policy and embarked on a multi- level cooperation with IPE. IPE also critically examines the zero-waster policies of leading European companies and published a ranking of major companies in China.

IPE is led by the journalist turned activist Ma Jun and receives support from the Rockefeller Foundation, the Energy Foundation, the Oak Foundation, and the See Foundation, the latter providing being the biggest financial support. In the interview, Ma Jun referred to the significant progress made on publishing pollution data after the policy revision in 2011, in particular P.M. 2.5. He also quoted examples of provincial level governments, such as Shandong government, to collaborate with IPE, on publishing the names of polluting industries on government websites (interview with Ma Jun on March 16, 2016).

\subsection{In-Country Expertise}

The interviews with academics at renowned Universities revealed that academic specialisations in China, like in most countries, typically show a strong path dependency. Thus, it has taken some time to build up academic expertise in newly emerging policy fields such as environmental and as well as climate protection and sustainable development policies. Tsinghua University is in the process of establishing a chair on sustainable development with international funding support.

Practitioners agreed that there is more freedom in agenda setting in academia than in public administration or government affiliated think tanks. There is strong continuity in academic specialisations. Therefore, the number of senior researchers with interest and expertise in policy fields such as sustainable development and climate governancetwo policy areas that have only recently emerged in official discourses in China is still relatively low.

The growing international academic exchange with China, however, has contributed 
to a significant rise in research works on topics related to sustainable development. It was not possible to collect hard data on the growing numbers of Chinese $\mathrm{PhD}$ students in environmental policy departments, but the interviews with experts confirmed the observations made on conferences, e.g. at the Spring Campus Conference of the University Alliance for Sustainability in Berlin in April 2016. Today the Chinese Government is able to draw on a growing number and variety of high level expertise of different disciplinary nature related to sustainable development policies.

\subsection{International Cooperation}

China's support to the Agenda 2030 and the 17 SDGs has significantly grown in the process of intensified international negotiations on the way to the United Nations summit in September 2015. China's commitments at the national, provincial and local levels have gradually improved its image at the international level, in particular in the context of Paris agreement. State and non-state stakeholders have demonstrated eagerness to learn from and to join many international alliances and projects in the field of environmental and climate policies from city to city cooperation to global policy initiatives led by the United Nations.

While the positive influence of international cooperation has been highlighted by most of the interviewed experts, some reference should also been paid to a few critical assessments regarding China's international engagements. Some interviewed scholars mentioned China's pronounced commitment to the Principle of Common but Differentiated Responsibilities. According to those experts, this has made China a longstanding ally of many developing countries which are known to be laggards in climate and environmental policies. Developing countries have focused their arguments on the historical accumulations of emissions by industrial countries and have repeatedly rejected binding commitments for them. China's alliances with the BRICS countries also contributed to mitigate its support for ambitious environmental and climate protection policies. The relative vagueness of the term sustainable development, however, allowed the BRICS countries to stay on board of the Agenda 2030 process.

The growing number of international exchanges and cooperation of state and nonstate stakeholders, however, has exposed China with the co-benefits of sustainable development policies, in particular in the area of technological development and infrastructure development. China is also eager to learn from potentials and difficulties that other countries experienced in the context of structural adjustments and just transition policies as witnessed in the context of the international workshop on "Green Transition. A Common Challenge for Industrialised and Emerging Economies", organised by the Chinese Academy of Science, Institute of Sciences and Development and the Friedrich Ebert Foundation in September 2016 in Beijing.

\section{Conclusion}

The cross-cutting concept of sustainable development is adaptable to many policy issues of economic, social and environmental concern and presents a strong case for 
multi-stakeholder involvement in collaborative governance arrangements. It has proved to be a relevant reference concept to frame China's growing efforts to strike a balance between economic growth, social development and environmental protection and to promote stakeholder participation.

The participation of the Chinese political leadership in global sustainability events, the breadth of discourses, including global and home-grown discourses, the density of state and non-state institutions dealing with sustainable development objectives, the growing level of in-country expertise in mainland China, and the involvement of Chinese institutions in global dialogues and international cooperation have prepared the ground for growing collaborative governance arrangements in the field of sustainable development.

While the authoritarian features of the political system in mainland China remain obstacles for elevating collaborative governance arrangement in China to higher levels of eye-to-eye level cooperation and power sharing, the widespread promotion of policy experimentations and pilot projects offsets some of the constraints. The high level of competence and international exposure of stakeholders in China explain the confidence of many experts that China will be able to manage the transformation towards a more sustainable growth strategy and strike a better balance between economic, ecological and social development objectives in the future.

The political authorities have recognised the need to draw on scientific knowledge, talent and contributions from various state and non-state actors to advance and evaluate policies and practices related to the sustainable development agenda. China regards the sustainable development agenda, including the talks and negotiations on climate change, as an opportunity to play a leading role in global conferences and summits and to enhance its soft power, especially in times when foreign and security policy issues and media censorship cast a shadow on China's relations with the United States and other Western countries. The 13th FYP, new laws and regulations provide ample evidence that the concept of sustainable development ties well into many policy priorities of the Chinese government and corresponds well with the growing engagement of many competent stakeholders in China. Collaborative governance-with its focus on consensus-oriented deliveries of public goods-is a good conceptual fit for framing multi-actor approaches in China in the context of promoting and implementing an ambitious agenda for sustainable development.

\section{Funding}

The paper is based on a senior research stay in Beijing in spring 2016 that was supported by the University Alliance for Sustainability (UAS). Within the framework of the University Alliance for Sustainability, Freie Universität Berlin together with its four strategic partner universities: the Hebrew University of Jerusalem (Israel), the Peking University (China), St. Petersburg State University (Russia) and the University of British Columbia (Canada) will focus on sustainability as a comprehensive topic for collaborating in research, teaching, and campus management. 
The German Research Foundation and the Open Access Publication Funds of the Freie Universität Berlin covered the publication fees of this paper in the OJPS.

\section{References}

Abbot, K., Green, J., \& Keohane, R. (2012). Institutional Density and the Ecology of Public and Private Institutions in World Politics. Presentation at Princeton University, 5 November 2012.

Ansell, C., \& Gash, A. (2007). Collaborative Governance in Theory and Practice. Journal of Public Administration Research and Theory, 8, 543-571. http://dx.doi.org/10.1093/jopart/mum032

Bertelsmann Foundation (2016). Bertelsmann Transformation Index. http://www.bti-project.org

Bo, Z. (2015). China's New Environmental Minister: A Rising Star. The Diplomat.

Brown, T., Gong, T., \& Jing, Y. (2010). Collaborative Governance in Mainland China and Hong Kong: Introductory Essay. International Public Management Journal, 15, 393-404.

Center for Systemic Peace (2010/2015). The Polity Project. http://www.systemicpeace.org/polityproject.html http://www.systemicpeace.org/polity/China2010.pdf

China Daily (2016). China's NGOs Urged to Play a Bigger Role on Global Issues.

Emerson, K., Nabatchi, T., \& Balogh, S. (2011). An Integrative Framework for Collaborative Governance. Journal of Public Administration Research and Theory, Online.

EU SME Centre \& China-Britain Business Council (2015). Smart Cities in China. Sector Report. http://www.cbbc.org/cbbc/media/cbbc media/KnowledgeLibrary/Reports/EU-SME-Centre-Re port-Smart-Cities-in-China-Jan-2016.pdf

Florini, A., Lai, H., \& Tan, Y. (2012). China Experiments. From Local Innovations to National Reform. Washington DC: Brookins Institution Press.

Freedom House (2016). Freedom in the World 2016. https://freedomhouse.org/report/freedom-world/freedom-world-2016

Gippner, O., \& London School of Economics and Political Sciences (Eds.) (2016). Changing Waters: Towards a New EU Asia Strategy. Special Report, LSE Ideas, April 2016.

Green, F., \& Stern, N. (2015). China's New Normal: Structural Change, Better Growth, and Peak Emissions. Policy Brief 2015, London: Grantham Research Institute on Climate Change and the Environment.

Hart, C., Zhu, Y., \& Ying, J. (2015). Mapping China's Climate Policy Formation Process. Beijing: The Embassy of the Federal Republic of Germany and Norwegian Embassy.

Heberer, T., \& Senz, A. (2011). Streamlining Local Behaviour through Communication, Incentives and Control: A Case Study of Local Environmental Policies in China. Journal of Current Chinese Affairs, 40, 77-112.

Heberer, T. (2006). Party State im, Reich der Mitte Zum politischen System in China. WeltTrends, 14, 59-72.

Heilmann, S., \& Stepan, M. (2016). China's Core Executive Leadership Styles, Structures and Processes under Xi Jinping. Merics Papers on China Papers, Mercator Institute for China Studies.

Hu, A. (2014). China: Innovative Green Development. Berlin: Springer. http://dx.doi.org/10.1007/978-3-642-54962-5

Hu, A. (2015). Embracing China's "New Normal". Why the Economy Is Still on Track. Foreign 
Affairs. www.foreignaffairs.com

Huxham, C., Vangen, S., Huxham, C., \& Eden, C. (2000). The Challenge of Collaborative Governance. Public Management, 2, 337-358. http://dx.doi.org/10.1080/14616670050123260

Jing, Y. (Ed.) (2015). The Road to Collaborative Governance in China. New York: Palgrave Macmillan. http://dx.doi.org/10.1057/9781137542182

Kennedy, S. (2005). The Business of Lobbying in China. Cambridge, MA: Harvard University Press. http://dx.doi.org/10.4159/9780674039490

Kuhn, B., \& Zhang, Y. (2014). Survey of Experts on Climate Change Awareness and Public Participation in China. Journal of Current Chinese Affairs, 43, 177-212.

Kuhn, B. (2016). Sustainable Development Discourses in the PR China. Public Lecture at the Institute of Sinology, Freie Universität Berlin on July 21, 2016; Draft Paper Accepted by the Journal of Sustainable Development for Publication in 12/2016.

Lan, Y. (2016). Typology of Co-Governance in a Strong-Government Context: Experience from China's Local Innovations. Unpublished Draft, Beijing: Tsinghua University, School of Public Policy and Management.

Lieberthal, K., \& Oksenberg, M. (1988). Policy Making in China: Leaders, Structures, and Processes. Princeton, NJ: Princeton University Press.

Lieberthal, K. G., \& Lampton, D. (1992). Bureaucracy, Politics, and Decision Making in Post-Mao China. Berkeley, CA: The Regents of University of California.

Liu, P. (2012). China Dream: A Lifestyle Movement with Sustainability at Its Heart. The Guardian.

Mertha, A. (2009). Fragmented Authoritarianism 2.0: Political Pluralization in the Chinese Policy Process. The China Quarterly, 200, 995-1012. http://dx.doi.org/10.1017/S0305741009990592

Ngar-in Mah, D., \& Hills, P. (2012). Collaborative Governance for Sustainable Development: Wind Resource Assessment in Xinjiang and Guangdong Provinces, China. Sustainable Development, 20, 85-97. http://dx.doi.org/10.1002/sd.466

Ostrom, E. (1990). Governing the Commons: The Evolution of Institutions for Collective Action. Cambridge: Cambridge University Press. http://dx.doi.org/10.1017/CBO9780511807763

Qi, Y, (2013). China's Commitment to a Green Agenda. McKinsey Quarterly, Online.

Qi, Y., \& Zhang, X. (Eds.) (2016). Annual Review of Low-Carbon Development Report in China (2015-2016). Beijing: Social Sciences Academy Press.

Ran, R. (2013). Perverse Incentive Structure and Policy Implementation Gap in China's Local Environmental Politics. Journal of Environmental Policy and Planning, 15, 17-39. http://dx.doi.org/10.1080/1523908X.2012.752186

Schroeder, P. (2014). Assessing Effectiveness of Governance Approaches for Sustainable Consumption and Production in China. Journal of Cleaner Production, 63, 64-73. http://dx.doi.org/10.1016/j.jclepro.2013.05.039

Stern, N. (2015). Why Are We Waiting? The Logic, Urgency, and Promise of Tackling Climate Change. Boston, MA: The MIT Press.

Sustainable Development Knowledge Platform (2015). https://sustainabledevelopment.un.org/hlpf/2016/china

Tiezzi, S. (2015). With Lower Growth Targets, China Pushes "New Normal”. The Diplomat.

United Nations Development Programme (UNDP) (2014). Governance for Sustainable Development. Integrating Governance in the Post-2015 Development Framework. Discussion Paper, New York: UNDP. 
United Nations Development Programme (UNDP) (2015). China, the Millennium Development Goalsand the Post-2015 Development Agenda. New York: UNDP.

United Nations' World Commission on Environment and Development (WCED) (1987). Our Common Future. New York: Oxford University Press.

Wang, Z., He, H., \& Fan, M. (2014). The Role of Ecological Marxism and Constructive Postmodernism-Beyond the Predicament of Legislation. Monthly Review, 66, 37-59.

http://dx.doi.org/10.14452/MR-066-06-2014-10 3

Weber, E. P. (2012). Unleashing the Potential of Collaborative Governance Arrangements: Getting to Robust Durability in the Blackfoot Valley. Journal of Sustainable Development, 5, 3547. http://dx.doi.org/10.5539/jsd.v5n7p35

Yang, L. (2015). Developing a Multicollaborative Governance System: A Meta-Analysis for the Inner Mongolia Grassland Region. In Y. Jing (Ed.), The Road to Collaborative Governance in China (pp. 95-122). New York: Palgrave Macmillan.

Ye, J., \& Fues, T. (2014). A Strong Voice for Global Sustainable Development: How China Can Play a Leading Role in the Post-2015 Agenda. Briefing Paper of the German Development Institute.

Zhang, J. Y. (2015). Cosmopolitan Risk Community and China's Climate Governance. European Journal of Social Theory, 18, 327-342. http://dx.doi.org/10.1177/1368431015579970

Zhao, R., Wu, Z., \& Tao, C. (2016). Understanding Service Contracting and Its Impact on NGO Development in China. VOLUNTAS, 27, 2229-2251.

http://dx.doi.org/10.1007/s11266-016-9714-3

Submit or recommend next manuscript to SCIRP and we will provide best service for you:

Accepting pre-submission inquiries through Email, Facebook, LinkedIn, Twitter, etc.

A wide selection of journals (inclusive of 9 subjects, more than 200 journals)

Providing 24-hour high-quality service

User-friendly online submission system

Fair and swift peer-review system

Efficient typesetting and proofreading procedure

Display of the result of downloads and visits, as well as the number of cited articles

Maximum dissemination of your research work

Submit your manuscript at: http://papersubmission.scirp.org/

Or contact ojps@scirp.org 